\title{
Assessing the 2014 Cadbury controversy through the Theory of Planned Behaviour
}

\author{
Faiswal Kasirye, Hassan Radwan \& Math Kreya \\ Department of Communication \\ International Islamic University Malaysia
}

\begin{abstract}
The purpose of this study is to assess the 2014 Cadbury controversy through the framework of the Theory of planned behavior. The study examined how Cadbury IMC campaign changed the attitudes, behaviors and the perceived behavioral control of the audience towards purchasing Cadbury chocolates. Content analysis was employed to analyze the Cadbury IMC video campaign that circulated widely during the saga in addition to the Cadbury social platforms that aided in data collection. Themes like Quality standards, halal certification, ingredients and supervision were generated from the data. The analysis of the data discovered, that Cadbury tried to involve the public while trying to resolve their halal certification issues as well as those related to the two bars that were in question. A number of issues were discovered in relation to TPB however, the study found out that there were underlying factors missing in most of the Cadbury campaigns carried out during the 2014 PIG DNA saga. So the government should consider establishing stringent mechanisms of controlling hala certification among Malaysian companies and those seeking to do business in the country at large.
\end{abstract}

Key words: Cadbury DNA saga, quality standards, hala certification, theory of planed behavior 


\section{INTRODUCTION}

In 2014 a controversial incident happened in Malaysia over the halal status of two Cadbury's chocolate items. It began from the Malaysian Ministry of Health (MoH) lab's tests that demonstrated that Cadbury's products were not fulfilling the essential conditions under the halal logo. This case was then invalidated by the Malaysian halal certification body, also known as JAKIM. The opposing claims from two trustworthy government sources astounded customers and influenced their purchasing behaviour (Ali, Xiaoling \& Sherwani, 2017). Internationally, this case

created uncertainty and confusion among Muslims. Additionally, the controversy significantly affected halal food consumption (Ali et al., 2017). In the halal industry, it is a common practice for a halal logo to be placed on food packaging.

For many shoppers, the logo is the fundamental source of reference. In the perspective of Muslim consumers, an item with a halal logo is a symbol that offers protection, both spiritually and physically. The Cadbury case, however, had shaken Muslim buyers' trust in the reliability of the halal certification. (Ali, Ismail, Alam, Makhbul \& Omar, 2018). Previously, studies on halal buying intentions had shown full buyer trust in halal certification. Nonetheless, little research has been conducted on halal purchasing intentions in various settings, including where certainty has been shaken after food scandals (Shah Alam \& Mohamed Sayuti, 2011). There are some positive and negative concepts that can be gained from this controversy. This paper gives a short chronology of the Cadbury controversy and attempts to separate some significant lessons from the issue.

\section{STATEMENT OF THE PROBLEM}

As many people grow worried about whether they were consuming a non-halal product, Cadbury had to step in to reassure the public that their product was safe and free from any pig related products. (Musa et. al, 2016) By providing a clear and broad message to the product through comprehensive public relations, they were able to comfort the public that their products are safe to 
consume. This is where our Integrated Marketing Communication (IMC) study focuses on. By extracting the marketing communication lessons done by Cadbury to save their image to the public.

Some of these marketing communication tools might include advertising, sales promotion and public relations to name a few. We can create an underlying framework to how corporations can improve their appearance towards the public

Moreover, throughout our research, we find that there are limited publications in context of halal food sector with regards the theory of planned behaviour (TPB). This is something that will be focusing on throughout our research as to shed light on The predictive validity and generalizability of a concept (Douglas and Craig, 2006). As Abdul Latif and Ayob (2014) noted, there aren't many topics that focus on the concept of TPB in relation to the halal market. this is a gap we would like to focus on.

The Cadbury incident that occurred in 2014 took everyone by surprise. With major Malaysian institutions giving conflicting results, people were left in a state of uncertainty and confusion about what was going to happen. This led to massive boycotts and protest from various people throughout Malaysia. Malaysian Islamic NGOs (Musa, Muslim, Omar \& Husin, 2016) were quick to jump to conclusions following the leak, creating further issues, rather than contacting Cadbury and seeking further qualifications on the issue.

Looking at this incident by using the theory of planned behaviour will further shed light on the Cadbury incident and the public's purchasing intentions. The theory of planned behaviour suggests that consumers will generally stay away from a product when they believe they have no power over the circumstance (Bonne et al., 2007). With the context of the current study, the halal status of Cadbury was in question after the scandal, there was a bewildering situation for halal food consumers. Therefore, reinstating their presence was a very important step in building trust with their customers. 


\section{RESEARCH QUESTIONS}

- How did the Cadbury IMC campaign change the attitudes of the target audience towards? purchasing Cadbury chocolates?

- subject norms that affected the target audience towards purchasing Cadbury chocolate?

- How did the Cadbury IMC campaign target the perceived behavioral control of the consumers in terms of purchasing Cadbury chocolate?

\section{LITERATURE REVIEW}

Several researchers concur, that in applying the theory of planned behaviour, the intention to consume identifies the belief of individual people in consuming food products based on halal label (Muhamad Yunus et al., 2014). The application of TPB in halal issues helps to explore the behaviour of the consumer in buying halal certified products (Mohamed Yunos et al., 2014). Started as the theory of reasoned action in 1980 to predict an individual's intention to engage in a behaviour at a specific time and place, the theory intended to explain behaviour over which people have the ability to exert self-control.

TPB has been used in more than 1000 studies and overall results have supported the theory (Ajzen, 2011). A study by Fife-Schaw in 2007 state that behavioural control is more important and significant on attitudes realization towards one's behaviour than behavioural beliefs and normative beliefs. Conner et al., (1998) applied the theory to try and understand drug compliance in a psychiatric population and they discovered that treatment intention is influenced by behavioural, normative and control beliefs. The strength of the theory has confirmed by several researchers (Trafimow et al., 2002; Hagger et al., 2002; Armitage \& Conner, 200; Armitage \& Conner, 2001; Fishbein \& Ajzen, 2009). 


\section{THEORETICAL FRAMEWORK}

\section{Theory of Planned Behaviour (TPB)}

TPB is one of the most widely used theories of consumer behaviour. It is an illustrative model developed by Icek Ajzen in 1985 which is used for a variety of behavioural intentions. The behavioural intentions consist of three main variables which are attitude toward the behaviour, subjective norm and perceived behavioural control (Lee, Cerreto, \& Lee, 2010).

Ajzen's Theory of Planned Behaviour (TPB) is a general model of human conduct. It states that one's behaviour is influenced by the intention to engage and attitudes toward the behaviour, perceived social norms, and perceived control over the behaviour (Ajzen, 1985). Attitude towards behaviour is characterized as individual assessment of the specific behaviour and expected behavioural beliefs. Perceived control is defined as the capability to manage a given behaviour based on beliefs about influences that control beliefs and performances. Intention to perform a behaviour is defined as one's drive to do a behaviour (Ajzen, 1985, 1991; Ajzen \& Fishbein, 1980).

This model has time and again been used in several studies regarding food labelling on purchasing behaviour among non-Muslim shoppers, for example, in a study by Abdul Latiff, (2013), respondents agreed, that Muslim consumers are hugely affected by the behaviour, attitude and subjective norm in respect to the products being advertised and bought.

The model states, that health-related behaviour is expected from the intention theory. Attitudes, subjective norms and perceived behavioural control influences intention towards the behaviour. The attitudes are considered as beliefs on the outcome of the health-related behaviour weighed by the value of the outcome. Subjective norm is the individual belief pondered by the level of compliance. While Perceived behavioural control is the individual belief that is weighed by perceived control generated by the above factors (Dumitrescu et al., 2011).

There are three main variables of TPB. The three main variables of TPB are known as attitude, subjective norm and perceived behavioral control have been used widely by the scholars in this particular fields. 


\section{Attitude of the consumers}

This refers to the degree of a person's feelings toward a behaviour intention whether positive or negative. Whenever a person feels positively attached to any behaviour intention, meaning that the degree of possibility of that specific behaviour is more likely to be performed. In particular, It's the favorable or unfavorable evaluative reaction toward something or someone, exhibited in one's beliefs, feelings, or intended behaviour (Ajzen, 1991).

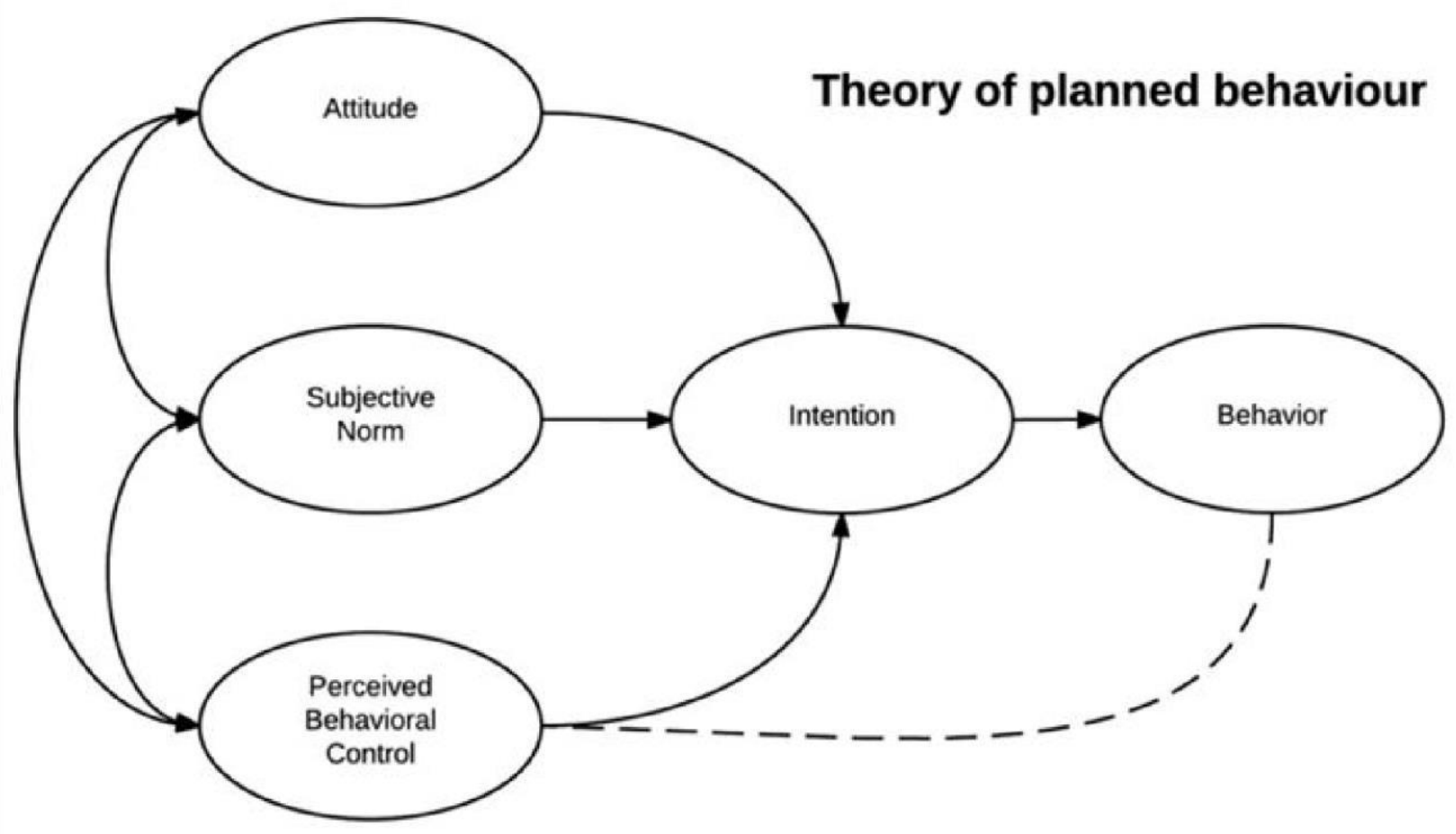

Figure 1 Framework illustrating the model for Theory of Planned Behaviour

According to Ajzen, if a person feels negatively attached to any specific behaviour intention, so that behaviour is more likely not to be performed. It means that, if they perceived Cadbury negatively (haram) then it's more obvious that they will not purchase and consume any Cadbury chocolate or product in the future. Attitude is usually the most powerful predictor of behavioral intention (Ajzen, 1991; Lim \& Dubinsky, 2005). 
In this sense, the attitude of Muslim consumers of Cadbury negatively perceived the incident since they are negative beliefs of pork in the Islamic religion because pork has been prohibited according the Quran. This belief caused deep effects on the Muslims in Malaysia from boycotting the Cadbury.

The Cadbury brand faced an extremely negative reaction in Malaysia after it developed clumps of chocolate that contained traces of pork, a substance prohibited by Islam. Muslims called a boycott of all Cadbury products and said that a sacred war, or Jihad, should be pursued against the organization. Additionally, they stated that the entire Cadbury production line in Malaysia should be closed down. Muslims said, that the Mondelēz-owned chocolatier was trying to deliberately weaken Malaysian Muslims with prohibited substances. In spite of the fact that Cadbury had pulled back its products in question, it experienced harsh criticism on its social media pages and has since tried to clarify the circumstances. A Cadbury representative said:

"We at Cadbury Malaysia understand that customers are disappointed to hear of the news on the recent test by the Ministry of Health on two of our products. We hear you and we value your comments and feedback over this issue.

We understand how important Halal is to the Muslim community. It is also of the highest importance to us here at Cadbury. Ensuring that all our products made here in Malaysia are Halal is something we take very seriously. Since our first learning of this, we have been actively engaging with the concerned authorities to investigate the issue with the highest urgency.

Meanwhile, we are withdrawing all impacted Cadbury Dairy Milk Hazelnut (with batch number 200813M01H I2 that expires on Nov 13, 2014) and Cadbury Dairy Milk Roast Almond (with batch number 221013N01R I1 that expires on Jan 15, 2015) immediately.

We would also like to reassure you that all other products made in Malaysia are not impacted by this test. We greatly appreciate your patience as we work through this matter." 


\section{Subjective Norms}

Subjective Norm in TPB, refers to the social environment around a particular person which towards a particular intention of performing certain behaviour. In another explanation, an individual has much concern to other people around them. If people around them such as Family members, friends, their community leaders and those who they think that they're important to that individual's life then their thinking will play an important role toward a behaviour intention of that individual.

Muslim respect their leaders so much to the extent that in any decision they make, they obey their prophet saying that obeying your leader is an obligatory. So the leader's command is effective among the ordinary Muslim.

"O you who have faith! Obey Allah and obey the Apostle and those vested with authority among you” (Quran 4, 159).

In the Cadbury case, members of the public like many Muslim NGO's came together conducting a news conference saying that Cadbury has "crossed the line" and they demanded for strict measures and action over the Cadbury Malay Mail Online that had been mentioned in the Huffpost by Yasmine Hafiz 2014.

In the conference, the united groups of Muslim NGOs in Malaysia said, that "They have betrayed us Muslim by putting haram elements through foods we consume in our bodies, to weaken us as Muslim” said Abu Bakar Yahya, the chief of Persaka Selangor. Ustaz Masridzi Sat, the president of Perkid said that most social problems involving Muslims in Malaysia come from the consumption of non-Halal food. "Because once someone eats pork it is difficult to guide him to the right path. When the day of judgment comes, that person will be wearing a pig-face because of what he was eating. We need to unite, we must declare jihad," he exclaimed.

In this case, the ordinary Muslims who are the most consumers of Cadbury in Malaysia perceived the ideas of haram in Cadbury as their leaders claim even if it's not officially proved by the official 
institution like JAKIM yet. Their perception and attitude had been built negatively towards Cadbury. According to Fishbein, the effects of subjective norm such as community leaders, family and friends tend to have more on the individual even if it's the weakest element compared to the other elements of TPB (Fishbein\& Ajzen, 1975).

The controversial incident happened in Malaysia over the halal status of two Cadbury's chocolate items. The controversial claim began from the Malaysian Ministry of Health $(\mathrm{MoH})$ that its lab tests demonstrated that the Cadbury products were not fulfilling the essential conditions under the halal logo. This case was then invalidated by the Malaysian halal certification body, also known as JAKIM. As a result, many Muslim groups were outraged by the events that transpired with Cadbury.

\section{Perceived Behaviour control}

Perceived behavioral control in the theory of Planned Behaviour refers to the perception of a person toward the performance of a specific behaviour whether it's difficult or easy (Ajzen, 1991). The individual will perceive positively whenever they feel that they have more confidence and more resources (Ajzen, 1985; Hartwich \& Barki 1994; Lee \& Kozar, 2005).

Reflecting on the Muslim reaction to the Cadbury scandal in Malaysia, the individual Muslim Cadbury customer are easily perceived the incident negatively. Their perception is built easily because their opportunity of receiving negative information is waste. The community have been talking about it, their family and the news and social media are discussing on the incident. Most of the information they received are negative. During that time, Cadbury Malaysia have not release any statement in order to proof the pureness from Pork DNA yet because they let the JAKIM and Ministry of Health investigate on the matter. This made the ambiguous decision and thinking of the consumers.

Muslims who eat halal eating regimens don't eat pork and its side-effects, liquor and creatures not butchered by Islamic procedures. Halal implies admissible by Islamic law and the term covers food and drinks as well as all issues of day by day life. The standard check for non-halal substances was 
directed by the ministry of health which throughout the end of the week declared that two Cadbury products contained hints of pork. Cadbury Malaysia, a piece of the British global claimed by Mondelez International, said it was pulling back two sweet treats, the Cadbury Dairy Milk hazelnut and Cadbury Dairy Milk roasted almond products. Syaikh Ismail Muhammad, the imam of the national mosque in Kuala Lumpur, said that intense action would serve in as a lesson to other food producers to guarantee their products were halal.

\section{Previous studies on TPB}

TPB has been used in many previous studies on the intention to purchase Halal products. Mohammed Omar (2012) in his study about the direct outcomes of halal products among Muslim consumers indicated that TPB is a perfect model in exploring the purchase of halal products. The study investigates effects of purchase intention and consumer confidence in halal products using TPB as the model. Abdul Latif and Ayob (2014) using the same theory (TPB) among Malaysian shoppers in Selangor on the effects of food labelling on consumer purchase behaviour generated a finding, that using food labels has a positive impact on the consumer purchase intention and behaviour.

A study conducted by Khalek 2015 on the determinants influencing halal food consumption among generation Y Muslims in Malaysian private universities shows that there is positive attitude of halal food among Generation Y. The finding contributed significantly to the increased level of their intentions in purchasing Halal food.

Additionally, TPB was also applied in a study by Ibrahim and Ismail (2015), and results indicate that religiosity positively impact on the consumer's intention to purchase halal labelled food stuffs. TPB has also been the source for some studies on consumer food choices and an important model in food-related behaviour. TPB model describes if the performance of an individual of a certain behaviour is determined by his or her intent to implement that behaviour (Shah Alam and Mohamed Sayuti 2011). 
On the other hand, the study of Ali et al, 2018 on the exploring of TPB in relation to a halal food scandal in Malaysia: The Malaysia Cadbury chocolate case shows that there is no significant relationship between attitude and intention to purchase Halal food.

Most of the studies about intention to purchase the Halal products that deployed TPB as the main theory were usually using quantitative approach. However, a few studies have been used TPB as the main factors in investigation on the intention to purchase the Halal product by using qualitative approach. One of them is the study conducted by Mahdi and Maryam 2015 on the country of origin effect on consumer purchase intention of Halal brand saying that most of the effective factors on consumer's intention to purchase halal products were based halal requirements, halal industry procedures, business environment, and manpower resources.

\section{HALAL MARKET IN MALAYSIA}

\section{Background}

There is no doubt that the Halal market is an extremely important trait in the scheme of global trading systems. With a Muslim population of over 2 billion, it is not only significant from a religious standpoint, but also from a social, economic and business perspectives. As of 2010, the halal market surpasses USD 650 billion dollars' ad is projected to reach 2.1 trillion in the coming years (International Markets Bureau, 2011).

Despite its vast growth, it is still a largely untapped market in many parts of the world and has many grounds to cover. Moreover, the literature on the markets and aspects that Halal covers is at its initial stage and suffers from a shortage in number of published materials. In addition, not much is mentioned on who are the major global players in the halal market and what factors have they contributed in the global trading process.

Malaysia has recently taken several long-term steps to participate in the national and international Halal market in response to the increasing demand for global Halal products and services. Such projects include the development of infrastructure for production and supply and the creation of Malaysia's international Halal center. In 2006, HDC and JAKIM were introduced to promote the 
structure of the Halal industry. Several institutions like HPRC and IKIM are collaborating nationally and internationally to develop Halal knowledge (Azman \& Tajul, 2012). Twenty halal parks have been developed in Malaysia to promote the development of the Halal industry, according to the Ministry of International Trade and Industry (MITI).

In Islam, Halal means 'acceptable or lawful' is a Quranic term according to Quran Surah 5: 87-88 "O you who have believed, do not prohibit the good things which Allah has made lawful to you and do not transgress. Indeed, Allah does not like transgressors. And eat of what Allah has provided for you [which is] lawful and good. And fear Allah, in whom you are believers (Ali 2001).”

The term halal and thoyyib (good) are also included in the same verses. The definition of thoyyib is the object that meets the requirements and or standards of quality, safety and wholesomeness as allowed in Islam. Halal is seen right from raw material's sourcing to the product's distribution, all the way to the delivery of products to customers (Hashim and Mat Hashim 2013).

Currently, there is a demand to put the labelling of halal on packed goods especially in 2014 Cadbury chocolate pig saga that occurred in Malaysia. Malaysia being a dominant Muslim country, halal labelling presents producers and sellers together with the rest of the world that are interested in halal labelled food stuffs with a wide understanding of the consumer's beliefs and thinking to properly understand their decision to purchase the different products. For example, the labels on the Cadbury chocolate are seen to influence buyers in choosing the product as argued by Hamdan et al., (2013). Additionally, in fact the presence of halal labels on every chocolate in the Malaysian market influenced buyers on their purchase intentions and therefore led to an increase in product sales. However, their market went down after an alleged discovery of Porcine DNA in two of their products during a routine halal check-up by the government.

\section{Cadbury management of the crisis}

During the virality of the 2014 Cadbury pig DNA saga, some NGOs demanded to have all Cadbury factories be closed in Malaysia because of the alleged discovery of the pig DNA in two of their favorite products on the market. Additionally, some organizations appealed to the public to boycott 
Cadbury in the whole country demanding if they are ready to wash and cleanse their blood veins of porcine after consuming Cadbury before the emergency of the aforementioned issues. Mondelēz had voluntarily recalled its products from shelves all over Malaysia after the traces of porcine DNA were found during a routine check for non-halal substances. Nonetheless, the recall failed to satisfy the consumers. Mondelēz continued to be the target of consumer boycotts nationwide, predominantly coming from leading Muslim non-governmental organizations (NGOs), (Norhayati Rafida, 2017). Within ten days of chaos, the company's sales world over had dropped unexpectedly and lost around USD37 million and was considering to relocate the factory to another country after having persistent public condemnation at large against all Cadbury related products (Norhayati Rafida, 2017).

\section{During the Controversy}

On the issue of the company's halal credibility, Mondelēz chose to remain silent whilst the matter was under investigation by the relevant authorities. At the same time, they showed their strong commitment to assist the authorities in all possible ways to ensure that investigations were conducted in the most transparent manner. However, the issue had been widely spread by the mainstream media and social media even during investigations. Instead of taking any action against controversy in the media, Mondelēz rather took the public sentiments seriously by giving full cooperation to the authorities wherever necessary. "We cannot do much, Azmira. Let JAKIM do their work. We provide every information as much as we can to facilitate the investigation" said Raja Zalina, Head of Corporate and Government affairs, Mondelēz International, Norhayati Rafida, (2017).

Farrell Tan, the founding director of Orchan Consulting said that Cadbury Malaysia is handling the issue well. Besides their speedy response and quick recall rate of the affected batches, they also seem to be cooperating well with the Ministry of Health on the next steps (Qistina Saim, 2014). On the other hand, managing director of Precious Communications Lars Voedisch lashed at Cadbury, that they did not address the issue as fast as they should and is not in control of the issue. 
"The perceived reality is that the rumors broke on social media first and then the government stepped in to order an investigation before the company took action and ordered recall. It makes the company look passive and reactive," (Qistina Saim, 2014).

\section{Post-Crisis Event}

Mondelēz tried handling the saga even better after the results of the investigation had been revealed to the public exonerating their two products of from having porcine DNA. Cadbury didn't issue any press release until JAKIM confirmed to the public that the Cadbury chocolate is halal. This made the public feel that Mondelēz Company is the victim of the alleged violation of halal act by the Ministry of Health. They were asked whether they want to take any action toward the Ministry of Health, who leaked the information that led to the controversy.

Additionally, after the results had been shown to the public that the two Cadbury chocolate products are purely halal already, they decided to jump-over the issue without taking any legal action towards anyone but only appealing to the government that the internal issues between $\mathrm{MOH}$ and JAKIM should be addressed before rushing out to the public because they are the consumers and they are expected to react the way they did (Musa at, el 2016). This statement made the public wonder on the two institution's internal issues and roles regarding Halal certificate.

TPB has been successfully applied by many researchers in their previous studies. It is considered as significant in studying consumer preferences in buying food products. It can be considered as a useful model for predicting the consumer purchasing behavior (Zulariff and Mohamad 2015). In the present study, TPB has been adopted because it has been proven before in predicting consumer behaviors towards hala food products, to which Cadbury as a food belongs.

\section{Theoretical framework}

The theory of planned behaviour (TPB) is one of the most widely used theories of consumer behaviour. It is an illustrative model developed by Icek Ajzen in 1985 which is used for a variety 
of behavioral intentions. The behavioral intentions consist of three main variables which are attitude toward the behaviour, subjective norm and perceived behavioral control (Lee, Cerreto, \& Lee, 2010).

Ajzen's Theory of Planned Behaviour (TPB) was adopted which is a general model of human conduct. It states that one's behaviour is influenced by the intention to engage and attitudes toward the behaviour, perceived social norms, and perceived control over the behaviour (Ajzen, 1985). Attitude towards behaviour is characterized as an individual assessment of the specific behaviour and expected behavioural beliefs. Perceived control is defined as the capability to manage a given behaviour based on beliefs about influences that control beliefs and performances. Intention to perform a behaviour is defined as one's drive to do a behaviour (Ajzen, 1985, 1991; Ajzen \& Fishbein, 1980).

This model has time and again been used in several studies regarding food labelling on purchasing behaviour among non-Muslim shoppers, for example, in a study by Abdul Latiff, (2013), respondents agreed, that Muslim consumers are hugely affected by the behaviour, attitude and subjective norm in respect to the products being advertised and bought.

The model states that health-related behaviour is expected from the intention theory. Attitudes, subjective norms and perceived behavioral control influences intention towards the behaviour. Attitudes are considered as beliefs on the outcome of the health-related behaviour weighed by the value of the outcome. Subjective norm is the individual belief pondered by the level of compliance. While Perceived behavioral control is the individual belief that is weighed by perceived control generated by the above factors (Dumitrescu et al, 2011). 


\section{METHODOLOGY}

\section{Research design and method}

This study adopts a qualitative research approach to provide a more in-depth understanding of what exactly happened and how did the public react to the Cadbury pig DNA saga in 2014. Qualitative research is grounded on the importance of understanding the rationale and justification behind people's attitudes (Curry, Nembhard \& Bradley, 2009).

Qualitative content analysis allows an inductive approach by generating frames from selected codes and guidelines of the Cadbury video content. Qualitative content analysis identifies underlying themes in the materials examined and supports them with brief quotations from the videos and text analyzed marking the inductive approach (Bryman, 2012). The study was an exploration of the theory of planned behavior and content analysis.

The inductive process of defining frames by identifying themes and codes (Hsieh \& Shannon, 2005 ) is possible for this study. There was need to perform an inductive and qualitative study due to the lack of predetermined frames in previous studies of similar nature. The lack of a structured process for identifying themes usually associated with the qualitative content analysis (Bryman, 2012) led the study in adopting the coding and Thematizing technique for Braun and Clarke (2006). Data analysis here comprised of Thematizing, coding and the categorization of data into different frames.

Researchers report using content analysis from this approach while analyzing manuscript types in a particular journal or specific content in textbooks or visual content. This type of analysis is an unobtrusive and a nonreactive way to study the subject of interest (Babbie, 1992). It can also provide basic insights into how words are actually used. However, findings from this approach may be limited by their distraction to the broader meanings in the data. 


\section{Data collection and analysis}

Data was digitally recorded and thematically analyzed in order to discover hidden meanings from a video advertisement that was done by Cadbury as their official response to reassure the public of their products in question. Selective analyses were carried out on several aspects of the video that are relevant to the research objectives and questions. Valid analysis is hugely aided by data displays that are focused enough to permit viewing of a full data set in one location and are systematically arranged to answer the research questions at hand." (Huberman and Miles, 1994, p. 432). Furthermore, Duranti (2006) explains, "A more valuable analysis is a more selective one, as irrelevant information makes the outcome difficult to read and might make the research purpose incomprehensible".

All approaches to qualitative content analysis require a similar analytical process of seven classic steps, including formulating the research questions to be answered, selecting the sample to be analyzed, defining the categories to be applied, outlining the coding process and the coder training, implementing the coding process, determining trustworthiness, and analyzing the results of the coding process (Kaid,1989).

Thematic analysis process in this study was employed from Braun and Clarke (2006) who described the phases of thematic analysis of transcripts as familiarizing yourself with your data, creating initial codes, looking for themes, reviewing themes and defining and naming themes.

Finally, to ensure the trustworthiness of qualitative research data, researchers are advised to undertake the audit-trail procedure (Carcary, 2009). The trail is carried out by way of providing the relevant documentation or transcripts to professional persons such as academicians, senior $\mathrm{PhD}$ researchers and others in the same category who are experienced in qualitative research studies to establish the trustworthiness of the findings from the study (Lincoln \& Guba, 1985; Anney, 2014).

For the present study, the video and its transcriptions will be given to experts who specialize in the English language and qualitative studies, for purposes of them being examined for accuracy by comparing and reviewing formulated codes and themes to qualify the meaning of the data. 
The Video that was obtained from the official Cadbury YouTube channel as well as the embedded comments under it from different social platforms helped us in recording the first impressions on the contents of the sample, which is essential in establishing the different study categories.

During the second phase of data interpretation, several aspects of the video will be considered including the content itself, graphic representation, theme and approach as well as the formal elements in the video. integration of text, font and text colour, integration of elements as well as identifying specific messages and what they mean for easy relation.

In the third level, the researchers shall focus on the analysis of the video itself. In order to define the data in the video, we shall label each data set according to its meaning as seen in the video. When realizing a concept, theme and approach will be considered as labels and other textual content integrated in video to anchor its meaning.

Due to the exploratory nature of this study, the researcher decided to use open variables to determine the content of the video and their theme framework. This procedure of analysis is in line with Huntington (2013) discursive perspective which helped in determining how concepts spread in a video advert effectively delivers the message to its intended audiences.

\section{Findings and Discussion}

In order to enable data processing and organization according to their ideal meaning, recoding of diverse items of the study will be done. In this phase, several content variables will be used considering establishment of common categories through an inductive process.

Apart from recoding variables, this phase will focus on establishing the interaction rate of the video with the public and whether Cadbury's intention was fulfilled. This will help to relate whether the content in the video achieved its primary goal through its degree of engagement with the public. 


\section{Coding and themes}

Codes

Halal status, packaging process, Auditing done under supervision to guarantee halal status

Supplies must pass procedures, Production process must abide by GMP, Safety and quality of food, Ingredients must go under a microbiology test, Approval from management divisions

Must be free from PIG contamination, Use of Fresh Ingredients

Regulations on raw ingredients, Suppliers are to be supervised at all times
Themes

Halal certification

Quality Standards

Ingredients

Supervision

The table above represents codes and themes extracted from the Cadbury IMC campaign that was distributed inform of a video to the public.

According to the table above, there are four dominant themes that were extracted from the data relating to Cadbury chocolate during the saga. The themes are: halal certification and quality standard. The themes are explained below in details.

\section{Halal certification}

This is one of the themes generated and agreed upon from the data extracted from the Cadbury video as well as other campaigns on their company social media platforms for this study. There are two codes that fall under halal certification and these are Halal status, packaging process. The first code states that halal status is an important aspect of the Malaysian culture. Many Malaysians provide an important emphasis on halal certification. They rely on it not only for religious purposes, but also on social, economic and business perspectives. This finding is supported by the

Qur'an, (5): 87-88 which says that believers must abstain from what Allah has made lawful. Allah 
(S.W.T) also advises us to eat what he has provided for us and stay away from what he prohibited us.

In Malaysian, Halal logo is a vital concern especially among the Muslim community. The Malaysian had amendment the law of TDA 2011 toward the use of only one Halal logo, i.e Malaysian Halal logo which is recognized by JAKIM. Without the Halal certification recognized by JAKIM or REFERENCES JAIN, is not allowed to be used. According to Malaysian law, Halal standards are developed through the consensus of the professional committees comprised by the consumers, producers and others relevant public group which approved by the Standard Malaysian Act 1996.

The second code under halal status is packaging process. It is a very important process that is very much reliant on the quality standards. The halal logo is always stamped on the packaging and must be displayed for everyone to see. The halal logo placed on the packaging provides a form of reassurance and quality for all consumers. There is another important quality that is very important. There must be no form of najis or impure foods in the packaging so as to hinder the quality of the food and may harm the individual that is eating the food.

The pictures above are some of the campaigns that Cadbury rolled out during the saga to further ease and assure consumers that their products are safe and healthy to consume.

The third and last code is 'Auditing done under supervision to guarantee halal status'. There is no doubt that the halal status is the foundational basis for all of their products. In order to meet their halal standards, a comprehensive form of auditing must be done to ensure to meet all these standards. Moreover, the government makes sure that the auditing process at Cadbury is done under strict formalities in order to guarantee and are fit to gain the halal status

\section{Quality Standards}

Quality standards is the second theme was generated from the data. This agreed among researchers that the quality standards when conducting the research. The codes under this theme are Supplies passing procedures, Production process must abide by GMP, Safety and quality of food, Ingredients must go under a microbiology test, Approval from management divisions. 
The first code for quality standards is supplies pass quality procedures. It is very important that they exceed the quality meet by the demands of Cadbury. In order for Cadbury to sell its products to millions of people, there must be a form of quality control and procedures that ensure their quality is safe for everyone to eat. They mentioned this statement meticulously in the video provided to the consumers in order to provide assurance in their products.

The second code for quality standards is Production process abiding by GMP. This context is defined as Good Manufacturing Practice (GMP). Which means that it is a system for ensuring that products are consistently produced and controlled according to quality standards. This is one of the issues that Cadbury stressed on producing their products during the controversial incident.

Safety and quality of food is another code generated under quality control which means, during the saga, Cadbury put much of their efforts in assuring the public that their products go through safety and quality food measure to ensure that the public is at ease with what they eat. This is an assurance that the two products that were in contention were actually safe and of good quality.

The forth code is 'Ingredients must go under a microbiology test'. This is an extremely important aspect of the Cadbury campaign. The microbiology test ensures the consistency of the chocolate, ensuring the taste and sweetness of the product once it is eaten. It is also done to ensure that it does not melt or decay under a certain temperature or humidity. The test also helps to shed light on the ingredients used and how they go with each other in combination.

The last code is about getting 'approval from management divisions'. This particular code concerns the logistical process of getting the product from factory to consumer. It also stresses on how it meets the government regulations as well as determining the price and profit margins of the product. These approval is a vital aspect in the overall process in rolling out the product to the customers. 


\section{Ingredients}

Ingredients is another theme created out of the data generated from the Cadbury video and its social media campaigns. The theme has the following codes under it: 'Must be free from PIG contamination, Use of Fresh Ingredients'.

The first code here talks about Cadbury products being free from pig contamination. This is one of the many assurances that JAKIM laws came to cure as all the food eaten in Malaysia should be designated halal basically because of the dominant number of Muslims in Malaysia. all Cadbury products are supposed to be certified by the halal bureau of Malaysia and therefore given halal certificate after certifying that the ingredients they use to manufacture their products are free from any pig contaminated materials.

Cadbury stresses in their video, that using fresh ingredients is one of the issues they take serious during the manufacturing of their products. This is done to make sure that the outcome of the products is safe from controversy like the one happened in 2014. This also helps in making sure that the taste of the product is kept constant to make sure that they keep it universal. These are also supervised by the Ministry of Health to ensure they meet the highest standards.

\section{Supervision}

Cadbury stresses that everything they do under intense supervision and scrutiny. This is one of the themes that were managed to be extracted from the data and its codes are 'Regulations on raw ingredients, Suppliers are to be supervised at all times,'

Regulations of raw ingredients are the fundamental basis that makes the chocolates. Therefore, Cadbury stresses that the raw ingredients are meticulously inspected to ensure that their products are of the highest quality. Cadbury also stresses that the raw ingredients gathered from other suppliers are also highly inspected and examined.

The next code is 'Suppliers being supervised at all times'. This particular code stresses the issue of accountability of the role that suppliers play in creating the Cadbury product. Ensuring that all 
their practices in and outside are of utmost trustworthiness. Cadbury must guarantee that any supplier that chooses to associate themselves with Cadbury must have a high level of consistency and quality products for Cadbury to rely on.

\section{Conclusion}

This paper was set out to investigate the 2014 Cadbury controversy under the framework of the theory of planned behavior. The results from the data analyzed indicates that Cadbury tried to involve the public while trying to resolve their halal certification issues as well as those related to the two bars that were in question. A number of issues were discovered in relation to TPB however, the study found out that there were underlying factors missing in most of the Cadbury campaigns carried out during the 2014 PIG DNA saga.

There are many lessons that came out of the Cadbury controversy. It showed the importance of the Halal logo in the Malaysian culture, where a number of Muslim organizations gathered to demonstrate to Cadbury in recognition of the importance of the halal logo on their products. This affected Cadbury especially after their products were boycotted nationwide.

Additionally, the unfortunate saga was a catalyst in the finishing of the halal analysis laboratory in Bandar Enstek, Nilai, Negeri Sembilan. This laboratory aided in the creation halal research and certification as well as the institute to understand more on the issue of halal knowledge. 


\section{References}

Abdul Latiff, Z. A. B., Rezai, G., Mohamed, Z., \& Amizi Ayob, M. (2016). Food labels’ impact assessment on consumer purchasing behavior in Malaysia. Journal of food products marketing, 22(2), 137-146.

Ajzen, I. (1991). The theory of planned behavior. Organizational behaviour and human decision

Ajzen, I. (2015). Consumer attitudes and behavior: The theory of planned behavior applied to Food consumption decisions. Rivista di Economia Agraria, 70 (2), 121-138.

Ali, A., Xiaoling, G., Sherwani, M. and Ali, A. 2017. Factors affecting Halal meat purchase intention Evidence from international Muslim. British Food Journal 119(3): 527-541.

Ali, M. H., Ismail, A., Alam, S. S., Makhbul, Z. M., \& Omar, N. A. (2018). Exploring the theory of planned behaviour (TPB) in relation to a halal food scandal: The Malaysia Cadbury chocolate case. International food Research Journal, 25, S79-S86.

Babbie, E. (1992). The practice of social research. Belmont, CA: Wadsworth. Journal of MultiDisciplinary Evaluation, 4 (7).

Blessings in Disguise. In Contemporary Issues and Development in the Global Halal Industry (pp. 95-104). Springer, Singapore.

Borzooei, M., \& Asgari, M. (2015). Country-of-origin effect on consumer purchase intention of halal brands. American Journal of Marketing Research $\quad, 1$ (1), 1-10.

Carcary, M. (2009). The research audit trail-enhancing trustworthiness in qualitative inquiry. The

Electronic Journal of Business Research Methods, 7(1), 11-24. case for interdependencies between salient beliefs. Psychology \& Marketing, 22 (10), 839.Communications of the ACM, 48(8), $72-77$. 
Curry, L. A., Nembhard, I. M., \& Bradley, E. H. (2009). Qualitative and mixed methods provide unique contributions to outcome research. Circulation, 119(10), 1442-1452. https://doi.org/10.1161/CIRCULATIONAHA.107.742775.

Douglas, S. P. and Craig, C. S. 2006. On improving the conceptual foundations of international marketing research. Journal of International Marketing 14(1): 1-22.

Duranti, A. (2006). Transcripts, like shadows on a wall. Mind, Culture, and Activity.

Fishbein, M., \& Ajzen, I. (1975). Belief, attitude, intention and behaviour: An introduction to Hartwick, J., \& Barki, H. (1994). Explaining the role of user participation in information system Huntington, H. E. (2013). Subversive Memes: Internet Memes as a Form of Visual Rhetoric. International Journal, 13(4), 301-310. https://doi.org/10.1207/s 15327884mca1304.

Kaid, L. L., \& Wadsworth, A. J. (1989). Content analysis. Measurement of communication behavior, 197-217.

Khalek, A. A. (2015). Determinants Influencing Halal Food Consumption Among Generation Y Muslims in Malaysian Private Universities. (Doctoral dissertation, Jabatan Siasah Syar'iyyah, Akademi Pengajian Islam, Universiti Malaya). P186.

Lee, Y., \& Kozar, K. (2005). Investigating factors affecting the anti-spyware system adoption. Lim, H., \& Dubinsky, A.J. (2005). The theory of planned behavior in e-commerce: Making a Lincoln, Y. S., \& Guba, E. G. (1985). Naturalistic inquiry. Beverly Hills, CA: Sage.

Muhamad, N., \& Latiff, Z. A. (2018). Factors Affecting the Intention to Purchase Halal-Labelled Chocolate Bar

Musa, N., Muslim, N., Omar, M. F. C., \& Husin, A. (2016). The Cadbury Controversy:

Nursalwani, M., \& Zularif, A. L. (2017). The effect of attitude, subjective norm and perceived behaviour control towards intention of Muslim youth at public universities in Kelantan to consume halal labelled chocolate bar product. Canadian Social Science, 13 (2), 43-48. 
Pacho, T. (2015). Exploring participants' experiences using case study. International Journal of Humanities and Social Science, 5(4), 44-53. Retrieved from http://www.ijhssnet.com/journals/Vol_5_No_4_April_2015/5.pdf.

Planing, P., \& Britzelmaier, B. (2011). A critical literature review on consumer acceptance of product innovations. International Journal of Management Cases , 13 (3), 235-241. processes, 50, 179-211.

Product in Kelantan. In Proceedings of the 3rd International Halal Conference (INHAC 2016) (pp. 455-466). Springer, Singapore.

Quran, Chapter 4 (an-Nisa), verse 59. Retrieved from https://www.al-islam.org/new-analysi s wahhabidoctrines-muhammad-husayn-ibrahimi/absolute-obedience-ruler. Access dated 14 November, 2019.

Saim, Q. (2014, May 27). Porcine DNA crisis: Did Cadbury manage communications well? Retrieved from https://www.marketing-interactive.com/cadbury-recalls-two-products/. Shah Alam, S., \& Mohamed Sayuti, N. (2011). Applying the Theory of Planned Behavior (TPB) in halal food purchasing. International journal of Commerce and Management, 21(1), 820. theory and research. Reading, MA: Addison Wesley. use. Management Science, 40(4), 440-465. 7.

Yasmine Hafiz. (2014). Cadbury Malaysia upsets Muslims after pork DNA found 'halal' chocolate. Retrieved from https://www.huffpost.com/entry/cadburymalaysiamuslimspork-halal n 5404555. Accessed date 14 November 2019. 